\title{
Collaborative Problem Based Learning to Improve Metacognitive of Chemistry Students: Systematic Literature Review
}

\author{
Rusly Hidayah ${ }^{1,2}$ Fauziatul Fajaroh' ${ }^{2}$ Parlan² \& I Wayan Dasna $^{2}$ \\ ${ }^{1}$ Faculty of Mathematics and Natural Sciences, Universitas Negeri Surabaya, Indonesia \\ ${ }^{2}$ Faculty of Mathematics and Natural Sciences, Universitas Negeri Malang, Indonesia, \\ Email: rusly.hidayah.2003319@students.um.ac.id
}

\begin{abstract}
Increasing the metacognitive abilities of chemistry students is an indisputable output of the teaching and learning process today. Collaborative problem based learning is a learning method that has been tested and proven to be applied, especially in Western countries in increasing the metacognitive abilities of students, but it is still very minimal applied in Asian countries, including Indonesia. Thus, this study was conducted to explore previous studies that examined collaborative problem-based learning in improving students' metacognitive abilities. The research design used in this study is a Systematic Literature Review with the requirements of the inclusion of articles on collaborative problem-based learning in improving the metacognitive abilities of chemistry students, accredited national and international publications between 2010 and 2020, full text, journal articles, and open access. The results of the exploration that were carried out found 102 articles, then the title and abstract were read into 20 articles, and 4 articles were read in full, which fulfilled all the stipulated inclusion requirements. The results of the systematic literature review conducted in this study provide empirical evidence of literacy that problem based learning improves the metacognitive abilities of chemistry students. However, most of the research conducted still uses various instruments, which are not standardized and validated.
\end{abstract}

Keywords: Collaborative Problem Based Learning, Metacognitive, Chemistry Students and Systematic Literature Review

\section{Introduction}

Today's learning paradigm has shifted to the focus on creating students with high thinking abilities to be able to exist and survive in the age of knowledge (Corebima, 2016). Higher order thinking skills are important to be mastered by students to become individuals who can face all the problems of life in the future (Zubaidah, 2016), especially in the face of an increasingly competitive world of work. Therefore, universities as higher education institutions, like it or not, must shift the orientation and paradigm of the teaching and learning process to creating students with high thinking skills.

Emily \& Michaele (2012) said that metacognitive ability is one of the important higher order thinking skills for students. Metacognitive ability is important to direct every thinking process of students in learning (Peters, 2000). Learners with good metacognitive abilities show good learning achievements in the academic field (Basith, 2014). Metacognitive abilities are believed to be high-level cognitive abilities needed for knowledge management where students are required to set their own learning goals and determine appropriate learning strategies to achieve these goals. The responsibility of students also includes monitoring the learning process and changing learning strategies when necessary (Sastrawati, et al, 2011). Learners who are trained to use metacognitive strategies intentionally in their learning activities can 
make themselves independent learners. Metacognition is a valuable skill for an educational goal because it can help students become self-regulated learners who are responsible for their learning progress and adapt their learning strategies to achieve task demands.

The fact that has developed until now is that education in Indonesia is still dominated by a view that knowledge is a set of facts that must be memorized. Most classes still focus on lecturers as the main source of knowledge or information providers by not exploring students' metacognitive abilities. This fact almost occurs in most universities in Indonesia, including students of chemistry study programs. The results of preliminary observations made showed that less than $25 \%$ of lecturers tried to empower the metacognitive abilities of Chemistry students.

Chemistry teaching materials contain two aspects, namely processes and concepts (Ibnu, 2009). The subject of chemistry covers many issues surrounding the properties and changes of matter and the phenomena that accompany them. According to Carin in Susiwi et al., (2009) learning chemistry as learning science aims to explain natural phenomena must involve students' metacognition in experience (hands-on) so that understanding occurs (minds-on). Gaining an understanding of the material must go through an investigative process. Experiments carried out in laboratory work must be student-oriented (Odubunmi \& Balogun, 1991). Students must be directed to act as scientists who can collect, sort, and categorize data, make measurements, analyze relationships, and make conclusions. At a higher level, students are directed to formulate hypotheses, design problem solving, and carry out experiments (Ibnu, 2009).

One of the learning strategies that can accommodate the metacognitive abilities of chemistry students is the Problem Based Learning (PBL) strategy (Krishnaswamy, 1996. Problem Based Learning will lead to faster metacognition development in students compared to non-PBL learning (Khery, 2013). PBL has proven to improve the metacognition of students most effectively by a large number of studies (Abrami et al., 2015). The study conducted by Nuranna (2021) suggests quite successful results in offline learning compared to online learning when using PBL in Chemistry students. The latest classroom action research conducted by Setiawan (2020) concluded that the implementation of problem-based learning models can improve students' metacognitive skills in each cycle.

PBL views that learning is not just a process of memorizing concepts or facts, but the process of interaction between individuals and their environment. PBL can also develop the skills needed in the knowledge era (Yamin, 2008) because it can develop higher order thinking skills that are more critical, creative, and collaborative in acting (Trilling \& Fadel, 2012). Savery (2015) said Problem Based Learning (PBL) or in Indonesian called Problem Based Learning is a learner-centered learning approach and confronts students with unstructured problems to encourage students to collaborate in building their knowledge. Thus it can be said that PBL is a collaborative learning method (collaborative) that applies a new paradigm in learning theories, especially constructivism learning pioneered by Vygotsky who introduced the idea that learning is a social experience. First, individuals think individually to make personal meanings, then they test the results of their thoughts in dialogue with others to build the understanding they are discussing (Gagnon and Michelle, 2001). In other words, the collaborative learning model is inherent in problem based learning. 
The growing phenomenon shows that most educators and administrators of educational institutions in Indonesia still do not fully and fully implement PBL in the teaching and learning process while it is important for the teacher to keep track of the student's cognitive process (Khatimah \& Antonius, 2020; Hasib et al., 2021).

Educators in Indonesia tend to do the opposite, tending to emphasize authority, passive learning, and memorization (Gwee, 2008). Recent research by Mayasari et al., (2016) reports that most Indonesian lecturers assume that traditional memorization methods and direct teaching approaches are still more suitable to be implemented than student-centered methods such as PBL. This is following the East Asian teaching and learning culture which values conformity and harmony more, unlike the Western culture which tends to be individualistic and open to differences. This of course will be very counterproductive for increasing the metacognitive abilities of students.

However, research by Mayasari et al. (2016) is still in the form of assumptions that do not take into account the phenomenon of globalization of western culture which has proven that PBL is very effective in improving students' metacognitive abilities. Therefore, this study intends to verify PBL in improving the metacognitive abilities of students, especially chemistry students. The main question posed in this research is whether collaborative problem based learning can improve the metacognitive ability of chemistry students?

By doing this research, it is hoped that it can provide a synthesis for stakeholders of higher education in Indonesia, including the Government, advanced researchers, and education practitioners in various universities in Indonesia to consider collaborative problem based learning as a real practice of national education goals, especially in improving students' metacognitive abilities

\section{Methods}

This study uses a systematic literature review method, or commonly known as Systematic Literature Review (SLR). Petticrew \& Roberts (2006) say SLR is a literature review that follows a set of standard rules to identify and synthesize all relevant studies and provide an assessment of what is known from the topic under study. With the SLR you can get a more informative summary or synthesis of research as well as a comprehensive critique of research status. More importantly, a rigorous and reliable SLR allows us to understand the depth, breadth, and quality of various studies on a particular topic, making valuable contributions, which enables policymakers to formulate policies based on solid and complete research information by identifying research gaps that can form the basis for further research.

The SLR in this study was carried out by searching the results of scientific research publications using online article databases: Scopus, SINTA (Indonesian Research Database), and Google Scholar. The keywords used are Problem Based Learning/Problem-Based Learning Metacognitive Ability and Chemistry Students.

The search results found 102 articles related to the topic under study. Of the 102 articles, the abstracts were read and then reduced to 20 manuscripts by considering the suitability of the abstract content and inclusion requirements. Furthermore, 20 manuscripts were read in fulltext, and 4 manuscripts were obtained that matched all the inclusion criteria that had been set. The inclusion criteria for the article search carried out included: (1) Articles about collaborative problem based learning in improving the metacognitive ability of chemistry students; (2) 
Publication between 2010 and 2020; (3) Accredited and reputable National and International Publications; (4) Full text, journal articles and open access.

The process of searching and screening articles in this study is illustrated through the literature flow diagram in Figure 1.

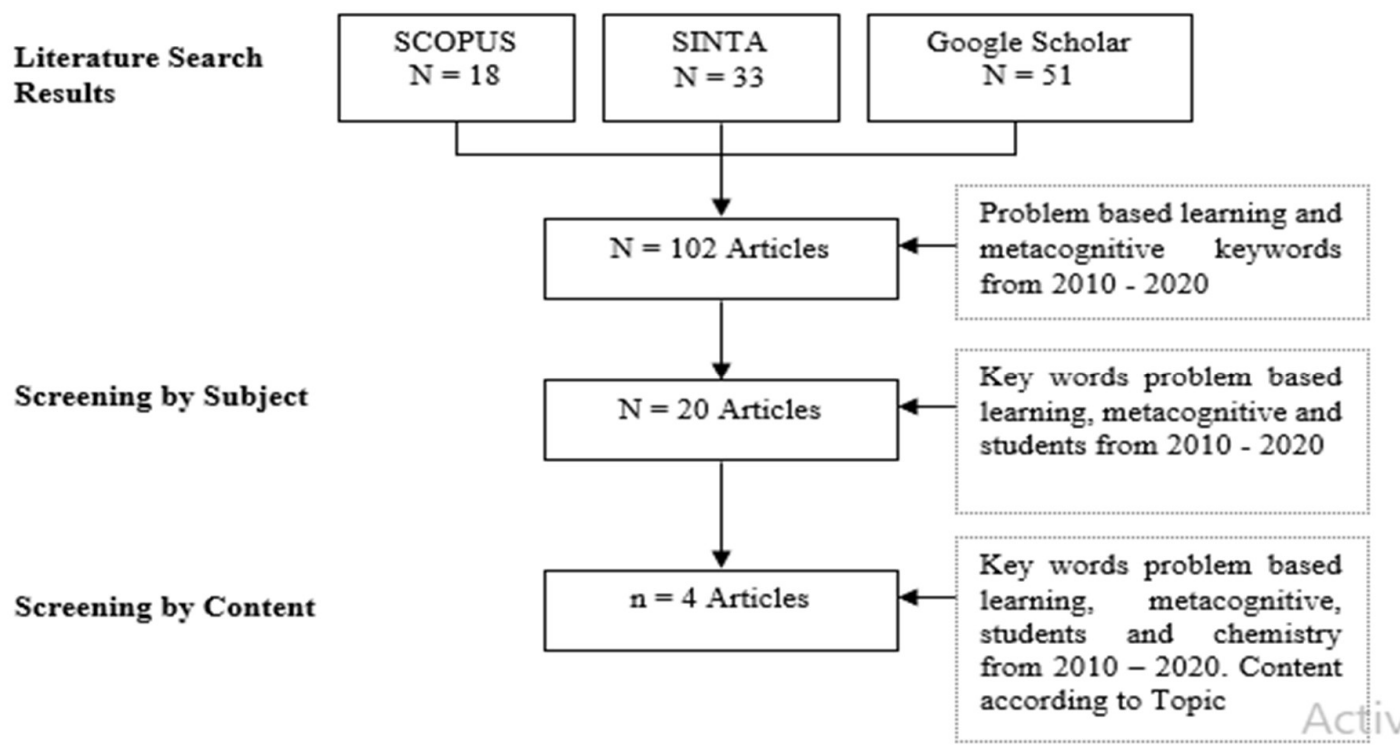

Figure 1. Literature Flow Diagram

The sample (n) articles that have met all the inclusion criteria, namely as many as 13 articles, were then analyzed using the narrative synthesis method used to analyze and synthesize the findings of all the studies reviewed. The narrative synthesis in this study followed three stages of Petticrew \& Roberts, (2006), namely extraction and coding, tabulation of codes (findings), and analysis of codes within and/or across all included studies. Furthermore, code extraction was carried out based on five elements of the study, namely, participants, intervention, comparison, results, settings to obtain materials that were important for analysis and synthesis (Petticrew \& Roberts, 2006).

The results of data extraction are then presented in a matrix to examine the findings and consider whether the research carried outreaches the same conclusion, the main function of the matrix is to present the findings in a well-organized way to help the synthesis process of the findings (Petticrew \& Roberts, 2006). The sample matrix of articles in this study is summarized in Table 1

Table 1. Sample Matrix (n) Articles = 3

\begin{tabular}{|l|l|l|l|l|l|}
\hline Author & Title & Country & Methods & Instrumen & Result \\
\hline Tosun and & The Effects of & Turkey & Quantitative & The & PBL is more \\
Senocak & Problem- & & with a quasi- & questionnaire & effective in \\
(2013). & Based & & experimental & with a Likert & developing the \\
& Learning on & & approach & scale was & level of \\
& Metacognitive & & with pre-and & distributed to & metacognitive \\
& Awareness & & post-test & 70 & awareness of \\
& and Attitudes & & group design & prospective & students with \\
\hline
\end{tabular}




\begin{tabular}{|c|c|c|c|c|c|}
\hline Author & Title & Country & Methods & Instrumen & Result \\
\hline & $\begin{array}{l}\text { toward } \\
\text { Chemistry of } \\
\text { Prospective } \\
\text { Teachers with } \\
\text { Different } \\
\text { Academic } \\
\text { Backgrounds. }\end{array}$ & & & $\begin{array}{l}\text { teacher } \\
\text { students }\end{array}$ & $\begin{array}{l}\text { weak scientific } \\
\text { backgrounds } \\
\text { compared to } \\
\text { those with } \\
\text { strong } \\
\text { scientific } \\
\text { backgrounds. }\end{array}$ \\
\hline $\begin{array}{l}\text { Haryani, et } \\
\text { al. }(2014) \text {. }\end{array}$ & $\begin{array}{l}\text { Developing } \\
\text { Metacognition } \\
\text { of Teacher } \\
\text { Candidates by } \\
\text { Implementing } \\
\text { Problem } \\
\text { Based } \\
\text { Learning } \\
\text { within the } \\
\text { Area of } \\
\text { Analytical } \\
\text { Chemistry. }\end{array}$ & Indonesia & $\begin{array}{l}\text { Quantitative } \\
\text { with a quasi- } \\
\text { experimental } \\
\text { approach } \\
\text { with pre-and } \\
\text { post-test } \\
\text { group design }\end{array}$ & $\begin{array}{l}\text { A } \\
\text { questionnaire } \\
\text { with a Likert } \\
\text { scale was } \\
\text { distributed to } \\
20 \\
\text { prospective } \\
\text { teacher } \\
\text { students }\end{array}$ & $\begin{array}{l}\text { Metacognitive } \\
\text { development of } \\
\text { the } \\
\text { experimental } \\
\text { class, with the } \\
\text { highest } \\
\text { metacognitive } \\
\text { indicators } \\
\text { achieved in } \\
\text { identifying } \\
\text { information } \\
\text { and the lowest } \\
\text { in developing } \\
\text { procedures. } \\
\text { The } \\
\text { development of } \\
\text { metacognition } \\
\text { followed by } \\
\text { mastery of } \\
\text { concepts or } \\
\text { vice versa is } \\
\text { much higher if } \\
\text { the contributor } \\
\text { is committed to } \\
\text { continuing to } \\
\text { innovate in } \\
\text { changing the } \\
\text { paradigm of } \\
\text { verification- } \\
\text { based } \\
\text { chemistry } \\
\text { laboratory } \\
\text { practice to be } \\
\text { open. } \\
\text { laboratory } \\
\text { practice, and } \\
\text { optimizing the } \\
\text { coaching } \\
\text { process with a } \\
\text { more solid and } \\
\text { consistent }\end{array}$ \\
\hline
\end{tabular}




\begin{tabular}{|c|c|c|c|c|c|}
\hline Author & Title & Country & Methods & Instrumen & Result \\
\hline & & & & & $\begin{array}{l}\text { contribution } \\
\text { team at every } \\
\text { stage of the } \\
\text { implementation } \\
\text { of problem- } \\
\text { based learning. }\end{array}$ \\
\hline $\begin{array}{l}\text { Muhali } \\
\text { (2014). }\end{array}$ & $\begin{array}{l}\text { Improving } \\
\text { Students' } \\
\text { Learning } \\
\text { Outcomes and } \\
\text { Metacognitive } \\
\text { Awareness in } \\
\text { Chemistry } \\
\text { Learning } \\
\text { Through the } \\
\text { Application of } \\
\text { Problem } \\
\text { Based } \\
\text { Learning } \\
\text { (PBL) } \\
\text { Models. }\end{array}$ & Indonesia & $\begin{array}{l}\text { Classroom } \\
\text { Action } \\
\text { Research } \\
\text { (CAR) }\end{array}$ & $\begin{array}{l}\text { Student } \\
\text { Worksheet } \\
\text { (LKS) n } 30 \\
\text { students }\end{array}$ & $\begin{array}{l}\text { Students' } \\
\text { metacognition } \\
\text { can be } \\
\text { improved } \\
\text { through the } \\
\text { application of } \\
\text { the PBL model } \\
\text { in learning } \\
\text { chemistry of } \\
\text { electrolyte and } \\
\text { non-electrolyte } \\
\text { solution } \\
\text { materials. }\end{array}$ \\
\hline $\begin{array}{l}\text { Ramdoniati } \\
\text { (2018). }\end{array}$ & $\begin{array}{l}\text { Development } \\
\text { of Problem } \\
\text { Based } \\
\text { Learning } \\
\text { Chemistry } \\
\text { Teaching } \\
\text { Materials to } \\
\text { Improve } \\
\text { Metacognition } \\
\text { Skills. }\end{array}$ & Indonesia & $\begin{array}{l}\text { Research and } \\
\text { Development. }\end{array}$ & $\begin{array}{l}\text { PBL-based } \\
\text { Student } \\
\text { Worksheet } \\
\text { (LKPD) on } \\
\text { electrolyte } \\
\text { and } \\
\text { nonelectrolyte } \\
\text { solution } \\
\text { material n } 94 \\
\text { students }\end{array}$ & $\begin{array}{l}\text { Problem Based } \\
\text { Learning-based } \\
\text { chemistry } \\
\text { teaching } \\
\text { materials are } \\
\text { feasible, } \\
\text { practical, and } \\
\text { effective in } \\
\text { improving } \\
\text { students' } \\
\text { metacognition } \\
\text { skills. }\end{array}$ \\
\hline
\end{tabular}

\section{Result and Discussion}

Research Results

Research related to the topic of problem based learning and metacognitive abilities has been carried out very much, both in Indonesia and abroad. Searching carried out in the last 10 years (2010-2020) in this study succeeded in collecting 102 articles related to the topic of problem based learning and cognitive abilities, but when entering the subject of students, especially chemistry students, there were only four articles. Furthermore, these four articles are the sample articles in this study. The four articles were read in full, and two articles were obtained using quantitative methods with a quasi-experimental approach with pre-and post-test group design (50\%), one article using classroom action research methods $(25 \%)$, and the rest using research and development methods ( $25 \%$ ). The majority of the research was conducted in Indonesia, with three articles, and the remaining one was conducted in Turkey. The earliest 
study was published in 2013 (Tosun and Senocak, 2013) and the most recent study was published in 2018 (Ramdoniati, et al. 2018). Although inclusion criteria were set to include studies ten years ago (2010), almost all studies included in the current systematic review ( $\mathrm{n}=$ 4) were published in the last five years (2013-2018). The total research subjects of the four articles in this study were 214 students. The study with the largest number of samples was studied by Ramdoniati, et al. (2018) with $\mathrm{n}=94$, and the smallest number of samples studied by Haryani, et. al. (2014), as many as $\mathrm{n}=20$ student-teacher candidates.

All sample articles in this study reported that PBL was effective in improving the metacognitive ability of chemistry students. Tosun and Senocak (2013) concluded that PBL is more effective in developing the level of metacognitive awareness of students with weak scientific backgrounds compared to those with strong scientific backgrounds; Haryani, et. al. (2014) concluded that the experimental class metacognitive development, with the highest metacognitive indicators achieved in identifying information and the lowest in developing procedures. The development of metacognition followed by mastery of concepts or vice versa is much higher if the contributor is committed to continuing to innovate in changing the paradigm of verification-based chemistry laboratory practice to open laboratory practice, and optimizing the coaching process with a more solid and consistent contribution team at every stage of the implementation of problem-based learning; Muhali (2014) concluded that students' metacognition can be improved through the application of the PBL model in learning chemistry of electrolyte and non-electrolyte solution materials, and Ramdoniati, et al. (2018) concluded that Problem Based Learning-based chemistry teaching materials are feasible, practical, and effective in improving students' metacognition skills.

The four articles in the study used different indicators in measuring PBL and metacognitive chemistry students. Tosun and Senocak (2013) used four PBL dimensions developed from Cheung (2009), namely: liking for chemistry theory lessons, liking for chemistry laboratory work, evaluative beliefs about school chemistry, and behavioral tendencies to learn chemistry. Meanwhile, to measure the awareness of the importance of metacognitive abilities of chemistry students, Tosun and Senocak (2013) adopted the eight dimensions of Schraw \& Dennison (2004), namely: declarative knowledge, procedural knowledge, conditional knowledge, planning, information management strategies, monitoring, debugging strategies and evaluating. These eight dimensions are also used in Muhali (2014) in measuring the awareness of the importance of the metacognitive abilities of chemistry students. PBL in Muhali's research (2014) was measured using four indicators Baron, et. al. (2003), namely: using problems in the real world, learning is centered on problem solving, learning objectives are determined by students and the teacher acts as a facilitator.

While metacognitive chemistry students. Haryani, et. al. (2014) in his research adopted six indicators developed from Pasha (2006) and Adani (2006) in measuring PBL, namely orienting students to the problem and conducting pretest, organizing students to study, supervising group examination, presenting the result of research, analyzing and evaluating the problem solving process, and students fulfilled the questionnaire responding to the implementation, had an interview, and took the posttest. Meanwhile, to measure the metacognitive ability of chemistry students, Haryani, et. al. (2014) adopted seven indicators developed from Anderson \& Krathwol (2001) and McGregor (2007), namely identifying information, elaborating information, applying comprehension, selecting procedure, developing procedure, interpreting data, and evaluating procedure. Lastly, research conducted by Ramdoniati, et al (2018) uses 
PBL indicators developed from Maiyuni and Maharani's (2016) research, namely the feasibility of content, language, presentation, and graphics. Meanwhile, the metacognitive ability of students is measured using self-developed indicators, namely predicting, planning, monitoring, and evaluating skills.

The dichotomy between standardized/commercial instruments and instruments developed by the researcher was used to code the instruments used in the studies reviewed. None of the studies reviewed included standard or commercial instruments. All studies measure or evaluate the metacognitive abilities of chemistry students using their developed instruments in various forms. Several researchers have developed and used a Likert scale measuring instrument (Tosun and Senocak, 2013 and Haryani, et al. 2014). Another study measured the metacognitive ability of chemistry students using student worksheets (Muhali, 2014 and Ramdoniati, et al. 2018)

Discussion

The systematic literature review carried out in the study contributes to the literature on the relationship between PBL and students' metacognitive abilities, especially chemistry students, by filling in several research gaps. PBL is a breakthrough strategy and method of learning that was created by Barrows to replace the traditional direct instruction curriculum in nursing schools. PBL refers to a curriculum with a constructivist approach that emphasizes actively assisting students with problem solving experiences on an actual case that occurs in real life (Savery, 2006). The traditional lecture teaching approach is irrelevant for students who will face the complex challenges of their future medical careers. Barrows' ideas resonate with the concerns of many medical educators who consider this issue important given the enormous demands of a career in healthcare and PBL's potential to prepare students for the challenges of the future.

Barrows' breakthrough was enough to get research enthusiasm from most of the systematic literature reviews in the health sector, including Kong, Qin, Zhou, Mou, \& Gao, (2014); Oh, Jeon, \& Koh, (2015); Shin \& Kim, (2013) who analyzed the study of the application of PBL in the nursing discipline. Dental education (Huang, Zheng, Li, Li, \& Yu, 2013), and general practitioner candidates (Koh, Khoo, Wong, \& Koh, 2008). Previous systematic reviews also noted that most PBL studies reviewed were in the context of faculty or health sciences (Gijbels, Dochy, Van den Bossche, \& Segers, 2005; Strobel \& Van Barneveld, 2009). This causes the subjects studied to be generally students who have a high initial learning capacity considering the selection and retention of learning in the health sciences is very competitive.

Along with the times and the shift in the paradigm of scientific civilization, the existence of PBL as a collaborative-based learning method and strategy is also growing. Not only is it suitable to be applied to the field of health science, but has also been applied to all scientific fields at all levels of education throughout the world, including Chemistry students in Indonesia.

This study was conducted unlike most previous, systematic reviews of research driven by different questions. The question is whether PBL which was originally formed and rooted in developed countries with Western ideology (individualism and liberalism) is effective in developing the metacognitive abilities of students in Indonesia who are identified as developing countries and tend to be based on eastern values (collectivism and conformity). This systematic 
review includes the implementation of PBL in chemistry students in Indonesia by identifying studies that need to be reviewed. This systematic literature review also aims to understand the methodological problems of PBL research in the Indonesian context which are usually rarely the focus of research by Indonesian scientists. Whereas economic and educational disparities in developing countries in Indonesia generally cause research quality that is not as good as in developing countries due to less access to literature and very small incentives for supporting research funds. Therefore, further analysis of the research methodology or literature reviewed is also carried out comprehensively.

Based on the research background as described previously, the main research problem questions from the systematic literature review in this study were formulated, namely: Does collaborative problem based learning improve the metacognitive abilities of chemistry students. Of the four studies identified in the systematic literature review in this study, all concluded that problem-based learning can improve the metacognitive abilities of chemistry students. However, these results need to be investigated further in terms of the research methodology that supports the results of the study. The systematic literature review conducted found three main problems that led to the conclusion of research results that support problembased learning to improve the metacognitive abilities of chemistry students.

The first problem is that the studies reviewed in this study report on different types of PBL frameworks with varying elements. The framework in these studies is certainly very important because it determines how PBL is implemented in the classroom and research. The problem occurs when some studies only consider some elements of PBL in their framework and ignore other elements, even almost ignoring the key elements of PBL Savery (2015) mentions that there are five key elements of PBL, namely actual problems, independent learning, a collaboration between students, educators as facilitators and the application of future professional skills. Overall research only defines PBL as a learning strategy that presents tasks in the form of problems or cases. The studies conducted seem to simplify the concept of PBL because of the explicit 'Problem Based' phrase in the name of the approach "Problem Based Learning" (literal translation of PBL). The error in oversimplification like this is something that Barrows has long warned about (2002), but the error continues to be found in many studies both globally and Indonesia as revealed in this study and a study conducted by Savery (2015). This shows that their misconceptions about what PBL is are something common even though the level of misconception will be higher in studies in Indonesia which generally rarely go through a rigorous review process when published. An important implication of this finding is how is it possible for researchers to conduct research and or teach using the PBL method, while the researchers/teachers do not fully understand the concept of PBL learning?

The second problem is that not all the literature studies in this study used reliable and validated elements. Of the four studies, only research by Haryani, et. al. (2014) reported on the instrument validation process and/or reported the psychometric values of the instruments used. Meanwhile, three other studies, namely Tosun and Senocak (2013), Muhali (2014) and Ramdoniati, et al. (2018) did not validate the instrument used, so the instrument used was less reliable.

The third problem is that the four studies that are systematically reported in this study do not adapt the vital component of PBL, namely the collaborative approach. The whole research that was written did not allow chemistry students to collaborate in solving cases. Even though it is 
very clear, Savery and Duffy (1995) say that social constructivism which lies at the heart of the PBL approach requires students to work together to produce solutions to problems through coordination and transaction of solutive ideas. Furthermore, Barrows (1986) said that group work is important in PBL because one of the basic goals of the PBL approach is to develop students' future professional skills, and working together in teams is one of these skills. Thus, studies that do not include group work do not understand the basic philosophy and ultimate goal of the PBL approach.

In today's era of technological advances which increasingly blurs geographical barriers, collaboration (collaborative) is the key to face the era of global competition. Lecturers as educators in higher education must be aware of this and understand that PBL can be a means to prepare students for future global challenges. Barrows (2002) and Savery (2015) in their research say the role of Lecturers in PBL is much more vital, although different from the role in traditional approaches. Lecturers in the PBL approach must be more careful in carrying out social engineering to ensure a learning environment that encourages collaboration and presents cases that remain challenging to stimulate students' learning passion. To date, it has been approximately fifty years since the PBL

approach was introduced by Barrows, and this learning approach has been developed by researchers around the world (Savery, 2015; Strobel \& Van Barneveld, 2009). A large number of studies have recognized PBL in improving metacognitive abilities, without exception the metacognitive ability of chemistry students. But ironically, as shown in this study, many educators have a wrong and/or partial understanding of PBL. It seems that the main reason for the misconceptions of educators and researchers is the lack of access to the latest PBL literature. In the studies reviewed, none of them cite the renowned PBL theorist Barrows (2002) or other prominent PBL proponents such as Strobel and Barneveld (2009) and Savery and Duffy (1995). Thus, it is hoped that the literature access of PBL educators and researchers is improved so that they can follow the latest findings and the consensus that occurs among PBL researchers.

The three studies in the study did not use standardized instruments of metacognitive ability, due to accessibility issues as well. The fact that all standard instruments are in English may limit the measurement because not many Indonesian students are fluent in English. While most standard instruments require moderate English reading skills, others are more reliable. This means English writing skills too. As a result, the standard metacognitive ability instrument demands too much for Asian students who are unfamiliar with academic skills, such as essay writing, and are not proficient in English (Green, 2007; Hidayati, 2009; Sommers, 2014). Sommers (2018) says there must be an adaptation of instruments for different languages and cultures of students so that instruments are not culturally biased and more accessible to all learners around the world. Sommers based his argument on the results of his systematic review which found that the majority of studies using standardized instruments reported lower metacognitive ability scores of Asian students compared to students in Western countries. This score reflects the discrepancy or bias of the instrument used to measure the metacognitive ability of students rather than the actual thinking ability of students.

In addition, the cause of the lack of use of standardized or commercial instruments in Asia, including Indonesia, is the cost constraint. Hatcher (2011) said Baker University in the US has experience using many standard instruments and the university costs expensive standard instruments. The cost of using the instrument can be doubled because the company that has the 
instrument license will charge a fee for presenting the instrument and reporting the measurement results

\section{Conclusion}

The systematic literature review in this study aims to analyze and at the same time find out collaborative problem based learning in improving the metacognitive abilities of chemistry students, and to test the extent to which the studies conducted have good scientific methodological strength. The results of a systematic literature review identified four studies that show problem based learning improves the metacognitive abilities of chemistry students. However, these studies have various PBL concepts and are not in line with the original concepts developed by leading PBL creators and experts such as Barrows and Savery. The vital concept of collaboration (collaborative) is not expressed in the PBL concept that has been tested in the studies conducted. With the scale or instrument used by the researcher - the research that is written in research is not standardized, not validated, and tested, thus raising doubts about the extent to which the results of the research carried out can be trusted. Therefore, it is recommended for future research to use a standardized, measurable, validated, and tested scale or instrument. PBL implementation should be done collaboratively because collaboration is a vital key that will never be separated from problem based learning methods. The results of a systematic literature review conducted in this study have proven to add to the long list of problem based learning implemented in collaboration to improve the metacognitive abilities of chemistry students. It is time for higher education stakeholders in Indonesia, including the Government, advanced researchers, and education practitioners in various universities in Indonesia to implement collaborative problem based learning into the real practice of national education goals and put them into national education regulations

References

Abrami, P. C., Bernard, R. M., Borokhovski, E., Waddington, D. I., Wade, C. A., \& Persson, T. (2015). Strategies for Teaching Students to Think Critically: A Meta-Analysis. Review of Educational Research, 85(2), 275-314. doi:10.3102/0034654314551063

Adani, G. (2006). New Project-Based Lab for Undergraduate Environmental and Analytical Chemistry. Journal of Chemical Education, 83 (2), 253-256.

Anderson, L.W., \& Krathwol, D.R. (eds). (2001). A Taxonomy for Learning Teaching and Assessing. A Revision of Bloom's Taxonomy of Educational Objectives.New York: Addison Wesley Longman, Inc.

Baron, Lissa, Jennie Preston-Sabin dan David Kennedy. (2013). Problem-Based Learning for the Pre-service Teacher. Summer, 22 (2), 329 -340.

Barrows, H. (1986). A taxonomy of problem-based learning methods. Medical education, 20(6), 481-486.

Barrows, H. (2002). Is it truly possible to have such a thing as dPBL? Distance Education, 23(1), 119-122.

Basith, A., Corebima, A. D., \& Zubaidah, S. (2014). Hubungan Antara Keterampilan Metakognitif Dan Pemahaman Konsep Biologi Siswa Kelas X pada Penerapan Strategi 
Problem-Based Learning dan Reciprocal Teaching di SMA Brawijaya Smart School Malang. Proceeding Biology Education Conference, 11(1), 818-824.

Corebima, A. D. (2016). Pembelajaran Biologi di Indonesia Bukan Untuk Hidup. Seminar Nasional XIII Biologi, Sains, Lingkungan, dan Pembelajarannya di Pendidikan Biologi FKIP UNS, 13(1), 8-22.

Emily, R. L., \& Michaele, V. (2012). No Title. National Council on Measurement in Education: Vancouver, B.C.

Gagnon Jr. George W. \& Collay Michelle. (2001). Designing for Learning Six in Constructivist Classrooms. California: Corein Press, Inc 7.

Gijbels, D., Dochy, F., Van den Bossche, P., \& Segers, M. (2005). Effects of problem-based learning: A meta-analysis from the angle of assessment. Review of Educational Research, $75(1), 27-61$.

Green, W. (2007). Write on or write off? An exploration of Asian international students' approaches to essay writing at an Australian university. Higher Education Research \& Development, 26(3), 329-344.

Gwee MCE (2008). Globalization of problem-based learning (PBL): Cross-cultural implications. The Kaohsiung Journal of Medical Sciences, 25 (3 suppl): S14-22

Haryani, Sri, Prasetya, Agung Tri dan Permanasari, Anna (2014). Developing Metacognition of Teacher Candidates by Implementing Problem Based Learning within the Area of Analytical Chemistry. International Journal of Science and Research (IJSR), 3 (6), 1223 - 1229

Hasib, M., Yassi, A. H., \& Nasmilah, N. (2021). Learner and Instructor's Perception on Discussion Technique in ELT. Journal Educational Verkenning, 2(1), 1-7.

Hatcher, D. L. (2011). Which test? Whose scores? Comparing standardized critical thinking tests. New Directions for Institutional Research, 2011(149), 29-39.

Hidayati, R. P. P. (2009). Peningkatan Kemampuan Menulis Esai Melalui Model Analisis Wacana Berorientasi Peta Berpikir Kritis Pada Mahasiswa Prodi Pendidikan Bahasa, Sastra Indonesia \& Daerah FKIP UNPAS Bandung. educationist, 10.

Huang, B., Zheng, L., Li, C., Li, L., \& Yu, H. (2013). Effectiveness of problem-based learning in Chinese dental education: a meta-analysis. Journal of dental education, 77(3), 377-383.

Ibnu, S. (2009). Kaidah Dasar Pembelajaran Sains. Makalah disajikan dalam kuliah Landasan Pendidikan dan Pembelajaran IPA, : Malang : PSSJ Pendidikan IPA, PPS Universitas Negeri Malang,

Khatimah, H., \& Antonius, A. (2020). The Significance of Teacher Mastery of Student Psychology in Teaching and Learning Process. Journal La Edusci, 1(5), 19-23.

Khery, Yusran (2013). Kesadaran Metakognitif, Proses Sains, dan Hasil Belajar Kimia Mahasiswa Divergen dan Konvergen dalam PBL. Jurnal Pendidikan Sains, 1(4), 343-351 
Koh, G. C-H., Khoo, H. E., Wong, M. L., \& Koh, D. (2008). The effects of problem-based learning during medical school on physician competency: a systematic review. Canadian Medical Association Journal, 178(1), 34-41.

Kong, L.-N., Qin, B., Zhou, Y.-q., Mou, S.-y., \& Gao, H.-M. (2014). The effectiveness of problem-based learning on the development of nursing students critical thinking: A systematic review and meta-analysis. International journal of nursing studies, 51(3), 458-469.

Krishnaswamy, N.R. (1996). Learning Organic Chemistry Through Natural Products: A Practical Approach. Resonance, 25-33.

Maiyuni, S dan Maharani, AD. (2016). Validitas Lembar Kerja Siswa (LKS) Berbasis Problem Based Learning Pada Materi Keanekaragaman Hayati Untuk SMA. Jurnal Pelangi. Vol 8(2) : 167-177.

Mayasari, T., Kadarohman, A., Rusdiana, D., \& Kaniawati, I. (2016). Apakah model pembelajaran problem based learning dan project based learning mampu melatihkan keterampilan abad 21? Jurnal Pendidikan Fisika Dan Keilmuan (JPFK), 2(1), 48-55.

McGregor, D. (2007). Developing Thinking; Developing Learning: A Guide to Thinking Skills in Education. Berkshire: Open University Press.

Muhali, (2014). Meningkatkan Hasil Belajar Dan Kesadaran Metakognitif Siswa Dalam Pembelajaran Kimia Melalui Penerapan Model Problem Based Learning (PBL). Prosiding Seminar Nasional FPMIPA IKIP Mataram, 329 - 336

Nuranna, N. (2021). Problem Based Learning Model Effectiveness in Improving Learning Achievement of Class X MIA Students on Newton's Law II Material in Offline and Online Learning. Journal La Edusci, 2(1), 28-34.

Odubunmi, O., \& Balogun, T.A. (1991). The effect of laboratory and lecture teaching methods on cognitive achievement in integrated science. Editor Ronald G. Good. Journal of Research in Science Teaching, 28(3): 213 - 224.

Oh, P.-J., Jeon, K. D., \& Koh, M. S. (2015). The effects of simulation-based learning using standardized patients in nursing students: A meta-analysis. Nurse Education Today, 35(5), e6e15.

Pasha, J.A. (2006). A Procedural Problem in Laboratory Teaching: Experiment and Explanation, or Vice-versa? Journal of Chemical Education: 83(1), 159-163.

Peters, M. (2000). Does Constructivist Epistemology Have a Place in Nurse Education? Journal of Nursing Education, 39(4), 70-166.

Petticrew, M., \& Roberts, H. (2006). Systematic Reviews in the Social Sciences: A Practical Guide. Oxford: Blackwell.

Ramdoniati, Nishfiya, Muntari dan Hadisaputra, Saprizal (2018). Pengembangan Bahan Ajar Kimia Berbasis Problem Based Learning Untuk Meningkatkan Keterampilan Metakognisi. JPPIPA, 5(1), 27-33 
Savery, J. R. (2015). Overview of problem-based learning: Definitions and distinctions. Essential readings in problem-based learning: Exploring and extending the legacy of Howard S. Barrows, 9, 5-15.

Savery, J. R., \& Duffy, T. M. (1995). Problem based learning: An instructional model and its constructivist framework. Educational technology, 35(5), 31-38.

Schraw, G. \& Dennison, R. S. 2004. Assessing metacognitive Awareness. Contemporary Educational Psychology. P. 460-475.

Setiawan, Tri Andri (2020). Penerapan Model Problem Based Learning Untuk Meningkatkan Kemampuan Metakognitif Mahasiswa Pendidikan Biologi. Jurnal Bioducation, 7(1), 8-13.

Shin, I.-S., \& Kim, J.-H. (2013). The effect of problem-based learning in nursing education: a meta-analysis. Advances in Health Sciences Education, 18(5), 1103-1120.

Sommers, C. L. (2014). Considering culture in the use of problem-based learning to improve critical thinking; Is it important? Nurse Education Today, 34(7), 1109-1111. doi:10.1016/j.nedt.2014.03.010

Sommers, C. L. (2018). Measurement of critical thinking, clinical reasoning, and clinical judgment in culturally diverse nursing students - A literature review. Nurse Education in Practice, 30, 91-100. DOI: https://doi.org/10.1016/j.nepr.2018.04.002

Strobel, J., \& Van Barneveld, A. (2009). When is PBL more effective? A meta-synthesis of meta-analyses comparing PBL to conventional classrooms. Interdisciplinary Journal of Problem-based Learning, 3(1), 4.

Susiwi, Hinduan, A.A., Liliasari, \& Ahmad, S. (2009). Analisis Keterampilan Proses Sains Siswa SMA pada "Model Pembelajaran Praktikum D-E-H". Jurnal Pengajaran MIPA, 14(2): 87-104.

Tosun, Cemal and Senocak, Erdal (2013). The Effects of Problem-Based Learning on Metacognitive Awareness and Attitudes toward Chemistry of Prospective Teachers with Different Academic Backgrounds. Australian Journal of Teacher Education, 36(3), 61-73

Trilling, B., \& Fadel, C. (2012). No Title 21st Century Skills: Learning for Life in Our Times. New York City: John Wiley \& Sons Inc.

Yamin, M. (2008), Paradigma Pendidikan Kostruktivistik, Jakarta : Gaung Persada Press.

Zubaidah, S. (2016). Keterampilan Abad Ke-21: Keterampilan yang Diajarkan melalui Pembelajaran. Seminar Nasional Pendidikan, 2(2), 1-17. https://doi.org/10.1021/acs.langmuir.6b02842 